\title{
Correction to: Vitiligo and tumor response in a patient with amelanotic melanoma undergoing nivolumab treatment
}

\author{
Satoshi Furune ${ }^{1}$ (I) Chiaki Kondo $^{1} \cdot$ Yuko Takano $^{1} \cdot$ Tomoya Shimokata $^{1} \cdot$ Mihoko Sugishita $^{1} \cdot$ Ayako Mitsuma $^{1}$. \\ Osamu Maeda ${ }^{1} \cdot$ Yuichi Ando $^{1}$
}

Published online: 26 October 2021

(c) The Author(s) 2021

\section{Correction to: International Cancer Conference Journal https://doi.org/10.1007/s13691-021-00515-w}

In the original publication, the section "Acknowledgments" is not be included. The Acknowledgments section is given in in this correction.

Acknowledgments This research was partly supported by AMED under Grant Number JP18ck0106463.
Open Access This article is licensed under a Creative Commons Attribution 4.0 International License, which permits use, sharing, adaptation, distribution and reproduction in any medium or format, as long as you give appropriate credit to the original author(s) and the source, provide a link to the Creative Commons licence, and indicate if changes were made. The images or other third party material in this article are included in the article's Creative Commons licence, unless indicated otherwise in a credit line to the material. If material is not included in the article's Creative Commons licence and your intended use is not permitted by statutory regulation or exceeds the permitted use, you will need to obtain permission directly from the copyright holder. To view a copy of this licence, visit http://creativecommons.org/licenses/by/4.0/.

Publisher's Note Springer Nature remains neutral with regard to jurisdictional claims in published maps and institutional affiliations.

The original article can be found online at https://doi.org/10.1007/ s13691-021-00515-w.

Satoshi Furune

s-furune@med.nagoya-u.ac.jp

1 Department of Clinical Oncology and Chemotherapy,

Nagoya University Hospital, 65 Tsurumai-cho, Showa-ku,

Nagoya 466-8550, Japan 